\title{
Desain dan Analisis Elemen Hingga Model Prosthetic Ankle-Foot
}

\author{
Zakki Fuadi Emzain ${ }^{1 *}$, Utsman Syah Amrullah², AM. Mufarrih ${ }^{3}$ \\ 1, 2, 3 Program Studi Teknik Mesin, Politeknik Negeri Malang \\ 1, 2, $3 \mathrm{Jl}$. Soekarno Hatta No.9, Malang, 65141, Indonesia
}

E-mail: zfemzain@polinema.ac.id ${ }^{1}$, utsman.syah@polinema.ac.id ${ }^{2}$, mufarrih@polinema.ac.id ${ }^{3}$

\section{Info Naskah:}

Naskah masuk: 14 Juni 2020

Direvisi: 27 Juli 2020

Diterima: 6 Agustus 2020

\begin{abstract}
Abstrak
Prostetik kaki merupakan salah satu kebutuhan bagi para difabel kaki sebagai alat bantu untuk beraktifitas. Model prostetik engkel kaki ini diusulkan sebagai salah satu alternatif model prostetik yang mudah dijangkau oleh para difabel. Model didesain dan dianalisis agar mampu menahan beban rata-rata berat manusia pada posisi heel strike, midstance, dan toe-off serta mempunyai nilai safety factor yang aman. Metode penelitian yang digunakan yaitu desain model dan analisis model yang terdiri dari preprocessing, solution, dan postprocessing. Hasil analisis menunjukan bahwa deformation terbesar terjadi pada posisi toe-off sebesar 1,52 $\mathrm{mm}$ ketika diberi load $500 \mathrm{~N}$ dan $0,036 \mathrm{~mm}$ ketika diberi moment $5000 \mathrm{Nmm}$. Strain energy terbesar terletak di area telapak kaki bagian depan pada posisi toe-off sebesar 0,6 mJ. Maximum stress juga terjadi pada posisi toeoff sebesar 5,71 MPa. Dengan safety factor 4,7 maka model tersebut terkategori aman karena stress yang terjadi masih dibawah batas yield strength dari material ABS.
\end{abstract}

\section{Keywords:}

design modelling;

equivalent stress;

finite element analysis;

prosthetic ankle-foot;

safety factor.

\begin{abstract}
Foot prosthetics is one of the needs of the disabled feet as a tool for activities. The ankle prosthetic model is proposed as an alternative prosthetic model that is affordable to people with disabilities. The model is designed and analyzed to be able to withstand the average weight of a human being in the heel strike, midstance, and toe-off position and has a safe safety factor value. The research method used is the model design and model analysis consisting of preprocessing, solution, and post-processing. The analysis results showed that the greatest deformation occurred in the toe-off position of $1.52 \mathrm{~mm}$ when given a load of $500 \mathrm{~N}$ and $0.036 \mathrm{~mm}$ when given a moment of $5000 \mathrm{Nmm}$. The greatest strain energy was located in the forefoot area at a toe-off position of $0.6 \mathrm{~mJ}$. Maximum stress also occurred at the toe-off position of 5.71 MPa. With a safety factor of 4.7, this model is categorized as safe because the stress that occurs is still below the yield strength limit of the ABS material.
\end{abstract}

\section{*Penulis korespondensi:}

Zakki Fuadi Emzain

E-mail: zfemzain@polinema.ac.id 


\section{Pendahuluan}

Penggunaan prostetik sebagai alat bantu pengganti organ tubuh yang hilang telah banyak digunakan di seluruh dunia dari kalangan difabel baik karena cacat sejak lahir atau amputasi karena penyakit. Di Indonesia pada tahun 2010 terdapat sekitar 11.580.117 jiwa penyandang disabilitas. Sekitar $16 \%$ dari penyandang disabilitas adalah tuna daksa dengan 1.852.866 jiwa [1]. Dari jumlah tersebut, baru sekitar $18 \%$ yang sudah menggunakan alat bantu. Sehingga masih banyak para tuna daksa yang belum menggunakan alat prostetik dikarenakan faktor ekonomi.

Hadirnya 3D printing sebagai salah satu dari teknologi rapid prototyping memberikan banyak manfaat dalam berbagai bidang. Dalam dunia medis penggunaan 3D printing yang umum digunakan yaitu untuk pembuatan jaringan dan organ, pembuatan prostetik, implan, dan model anatomi yang bisa dimodifikasi [2]. Dengan keunggulan yang mudah dalam modelling, cepat dalam fabrikasi, dan hemat biaya menjadikan 3D printer sangat tepat digunakan sebagai alternatif pembuatan alat prostetik [3].

Beberapa penelitian alat prostetik sebelumnya yang telah dilakukan ada yang bentuk surfacenya mirip seperti kaki manusia [4], ada juga yang fokus pada engkel dengan kemampuan fleksibel dan efisiensi energi balik [5][6]. Ada juga yang memiliki desain yang kecil, tipis, dan murah [7]. Ada juga yang menggunakan perangkat control dan sumber penggerak listrik [8][9]. Ada juga model prostetik yang menggunakan pegas, kopling, dan motor [10]. Namun dari beberapa penelitian yang semisal seperti tersebut diatas masih memiliki kekurangan yaitu model terlalu kompleks, sulit untuk penggunaan, berat, dan mahal.

Meskipun sudah banyak berbagai macam model prostetik yang dijual secara komersil dari harga yang sedang sampai yang mahal. Namun masih sulit dijangkau bagi para tuna daksa dari kalangan menengah kebawah. Sehingga perlu adanya model foot prosthetic yang ringan, mudah penggunaan, dan murah. Proses pembuatan foot prosthetic dengan 3D printing pun lebih mudah dan cepat dari pada pembuatan secara konvensional [11].

Masalah selanjutnya adalah jika ekperimen uji kekuatan dan perubahan bentuk dari prototipe prostetik dilakukan setelah proses cetak dari 3D printing akan didapati trial dan error dengan menyita biaya, waktu, dan tenaga. Pendekatan metode elemen hingga bebasis komputasi menjadi kunci solusi atas problem tersebut, suatu pemodelan dapat dianalisis nilai deformasi, tegangan, dan regangan yang terjadi secara detail [12]. Pemecahan problem numerik dengan komputasi akan menjadikan proses kalkulasi lebih cepat dibandingkan penghitungan teoritis matematik manual atau ekperimen di laboratorium dengan nilai yang mendekati riil [13].

Tujuan dari penelitian ini yaitu untuk merancang suatu model prostetik khusus pada bagian engkel kaki dan dilakukannya analisis menggunakan komputasi elemen hingga untuk mengetahui kekuatan dan perubahan bentuk model. Dimana model prostetik mampu menahan beban ratarata berat manusia dengan posisi sudut pada siklus berjalan serta mempunyai nilai faktor keamanan yang aman. Sebelum model tersebut difabrikasi menggunakan 3D printing dan menjadi prototipe untuk membantu para difabel kaki.

\section{Metode}

Proses penelitian ini terdiri dari dua tahapan utama yaitu desain model menggunakan software CAD dan analisis model menggunakan software analisis elemen hingga. Diawali dengan studi literatur untuk mencari referensi penelitian yang serupa dan bentuk-bentuk model foot prosthetic yang pernah diteliti. Tahap desain model adalah merancang desain foot prosthetic yang unik dan memiliki keunggulan daripada desain-desain sebelumnya.

Tahap selanjutnya adalah mensimulasikan dan menganalisis model seberapa kuat dan layak jika diproduksi dan diterapkan kepada pasien difabel yang terdiri dari preprocessing, solution, dan postprocessing. Preprocessing meliputi setting material parameter, meshing, boundary and loading condition. Solution meliputi setting analysis parameter sedangkan postprocessing meliputi analysis result display. Gambar 1 merupakan flowchart dari tahapan penelitian ini [14].

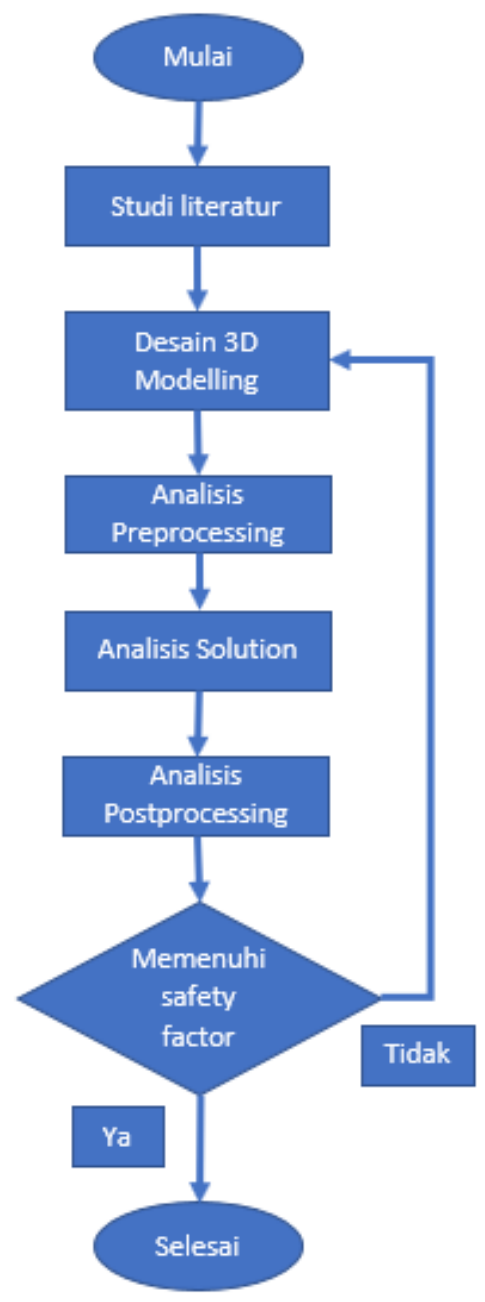

Gambar 1. Flowchart tahapan penelitian

\subsection{Desain Model}

Pada paper ini, prostetik engkel kaki didesain menggunakan software CAD Inventor 2018 dengan bentuk umum struktur yang menyerupai engkel kaki. Pada bagian ujung jari kaki hingga punggung kaki didesain dengan bentuk melengkung untuk memperhalus gerakan melangkah 
dari posisi tengah-tengah (midstance) menuju posisi ujung jari (toe-off). Bentuk melengkung tersebut juga dapat memberikan tambahan gaya dorong ketika penpindahan siklus berjalan dari fase berdiri (stance) menuju fase ke ayunan (swing).

Pada bagian mata kaki atau persendian engkel dirancang dengan bentuk melingkar supaya bisa memberikan gaya elastis kembali jika diberikan beban dari atas dan digunakan dalam sikus berjalan. Bentuk ronggarongga lengkung di dalam lingkaran pergelangan kaki dengan ketebalan sisi sekitarnya $10 \mathrm{~mm}$ dikonsep untuk mengurangi berat protetik engkel kaki, meringankan gerakan kaki ketika digunakan berjalan, menyerap tegangan, dan efisiensi ketika fabrikasi. Disamping itu dapat mengurangi kekakuan (stiffness) pada model serta bisa memberikan efek elastis pada prostektik engkel kaki.

Sedangkan bagian tumit berbentuk setengah lingkaran baik tampak samping dan atas supaya pergerakan tumpuan awal posisi tumit (heel strike) kontak dengan tanah berjalan secara lebih halus dan rongga lengkung bagian bawah dapat meredam tumbukan dengan ground. Pada bagian atas engkel kaki dibuatkan sebuah poros pendek sebagai soket penghubung dengan prostetik betis menggunakan baut sekrup sebagai penguncinya. Pada ujung jari kaki tampak atas diberikan fillet atau bentuk lengkungan untuk mengurangi sisi tajam pada model. Bentuk yang simestris menjadikannya dapat digunakan baik untuk engkel kaki kanan maupun engkel kaki kiri. Keterangan bagian prostetik engkel kaki dapat dilihat pada Gambar 2. Dimensi dan parameter model prostetik engkel kaki ini lebih detailnya ada pada Tabel 1 .

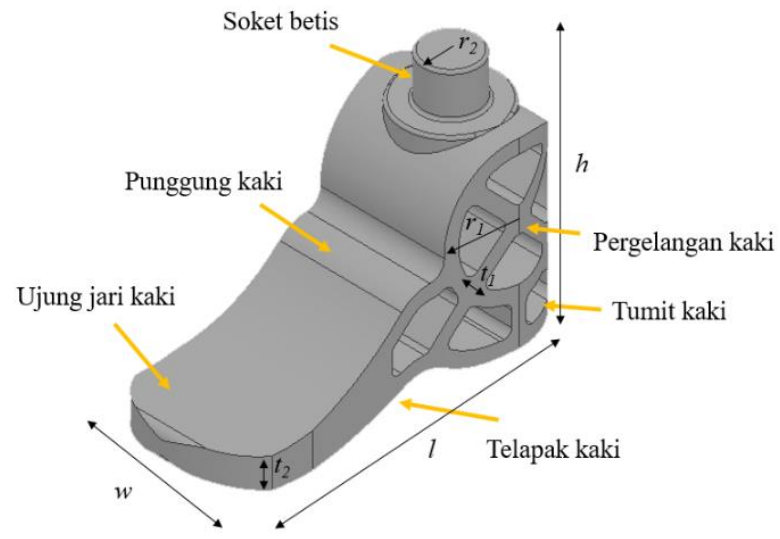

Gambar 2. Keterangan bagian dan simbol dimensi model

Tabel 1. Dimensi model prostetik engkel kaki

\begin{tabular}{lc}
\hline \multicolumn{1}{c}{ Keterangan } & Nilai $(\mathbf{m m})$ \\
\hline Panjang $(l)$ & 260 \\
Lebar $(w)$ & 100 \\
Tinggi $(h)$ & 160 \\
Ketebalan rongga sendi $\left(t_{l}\right)$ & 10 \\
Ketebalan ujung kaki $\left(t_{2}\right)$ & 20 \\
Radius sendi kaki $\left(r_{l}\right)$ & 50 \\
Radius soket betis $\left(r_{2}\right)$ & 20 \\
\hline
\end{tabular}

Dengan konsep desain yang melengkung dan ronggarongga lengkung menggunakan konsep mekanisme elastis (compliant mechanism) diharapkan dapat memberikan fleksibelitas model ketika dilakukan gerakan siklus berjalan. Disamping itu adanya energi regangan (strain energy) yang tersimpan baik di bagian ujung kaki, di bagian sendi, dan di bagian tumit prostetik engkel kaki dapat memberikan gaya lentur ketika berjalan. Sehingga pegas pasif yang biasanya terdapat pada model prostetik konvensional dan memaksa penderita yang kakinya teramputasi untuk berjalan secara tidak wajar bisa teratasi.

Konsep strain energy yang didesain adalah menyimpan energi tegangan (stress) dari beban (load) dan akan dikembalikan energi tersebut saat load dilepas untuk memberikan gaya dorong balik ke kaki. Selain itu, model desain dengan konsep compliant mechanism dan strain energy yang ada, model ini diharapkan dapat membantu orang yang diamputasi kakinya bisa bergerak melangkah dan berjalan menyerupai gaya berjalannya manusia yang normal. Rancangan prostetik engkel kaki ini didesain meniru bio mekanika, gerakan biologis, dan fase atau siklus manusia berjalan. Desain prostetik engkel kaki dengan struktus statis aktif ini juga mampu mendukung rehabilitasi berjalan awal bagi pasien yang diamputasi pada kakinya.

\subsection{Analisis Model}

Pada model prostetik engkel kaki ini dilakukan analisis elemen hingga untuk menganalisis perilaku struktur pada model dan mengetahui deformasi keseluruhan (total deformation), tegangan ekuivalen (ekuivalen stress), dan energi regangan (strain energy) dengan menggunakan software ANSYS 19.2 Workbench. File geometry yang digunakan berformat IGES hasil export dari Autodesk Inventor.

Material yang digunakan adalah acrylonitrile butadiene styrene (ABS) diinput secara manual kedalam engineering data dengan karakteristik mekanik seperti pada Tabel 2 [15][16]. Material ABS dipilih karena memiliki filament yang lebih ringan (lighter filament), lebih tahan lama (durability), dan lebih tahan panas (heat resistance) dibandingkan PLA dan Nylon.

Pada tahap penjaringan elemen (meshing) digunakan ukuran elemen sebesar $5 \mathrm{~mm}$ diinput secara manual seperti pada Gambar 3. Skala Skewness digunakan sebagai kriteria evaluasi kualitas elemen.

Tabel 2. Karakteristik mekanik material ABS

\begin{tabular}{lc}
\hline \multicolumn{1}{c}{ Karakteristik } & Nilai (unit) \\
\hline Density & $1400 \mathrm{Kg} / \mathrm{m}^{3}$ \\
Young's modulus & $2400 \mathrm{Mpa}$ \\
Poisson's ratio & 0,37 \\
Yield strength & $26,84 \mathrm{Mpa}$ \\
\hline
\end{tabular}




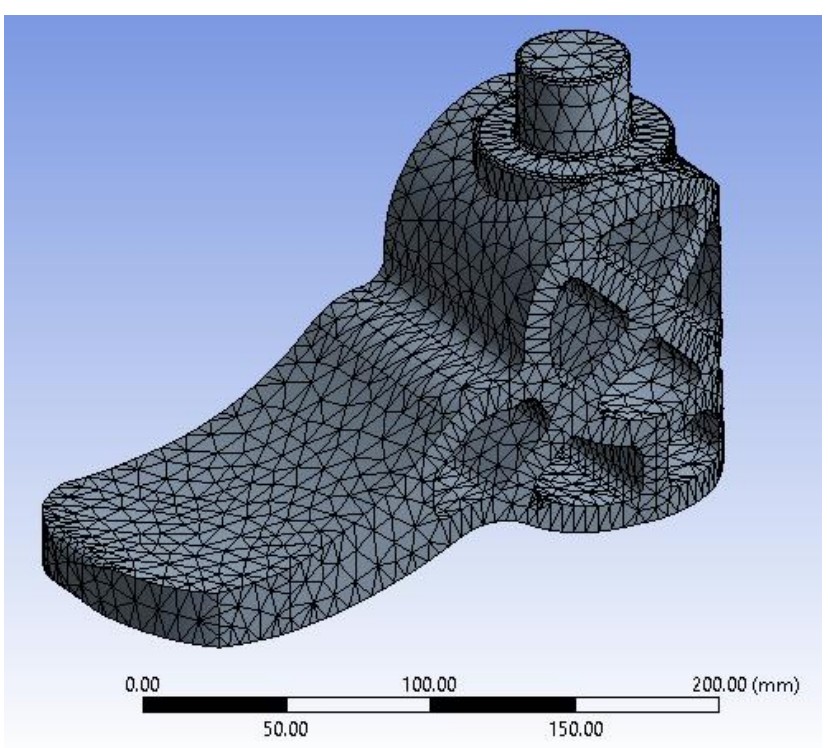

Gambar 3. Bentuk meshing model

Pada Gambar 4 menampilkan jumlah elemen terbanyak ada diantara metrik elemen $0,25-0,5$. Berdasarkan skala Skewness itu menujukkan bahwa kualitas elemen terkategori bagus. Tahap meshing ini menghasilkan 33980 node dan 19371 elemen.

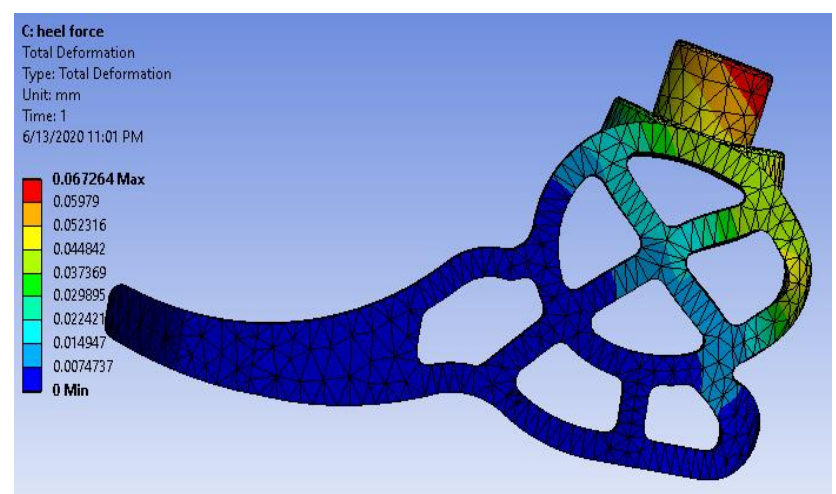

$(\mathrm{a}$

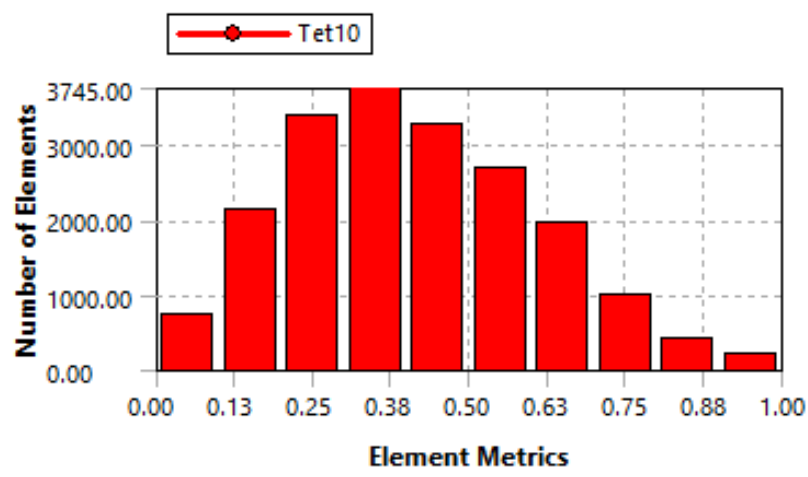

Gambar 4. Hasil kualitas meshing dari jumlah elemen

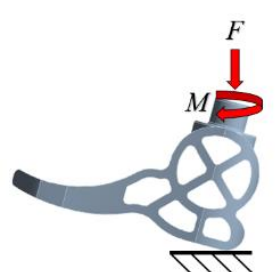

(a)

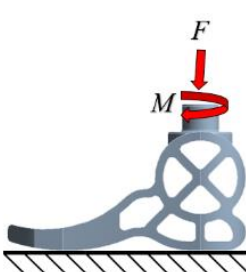

(b)

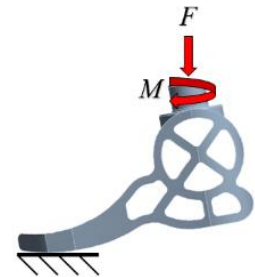

(c)
Gambar 5. Boundary condition model (a) posisi heel strike; (b) posisi midstance; (c) posisi toe-off

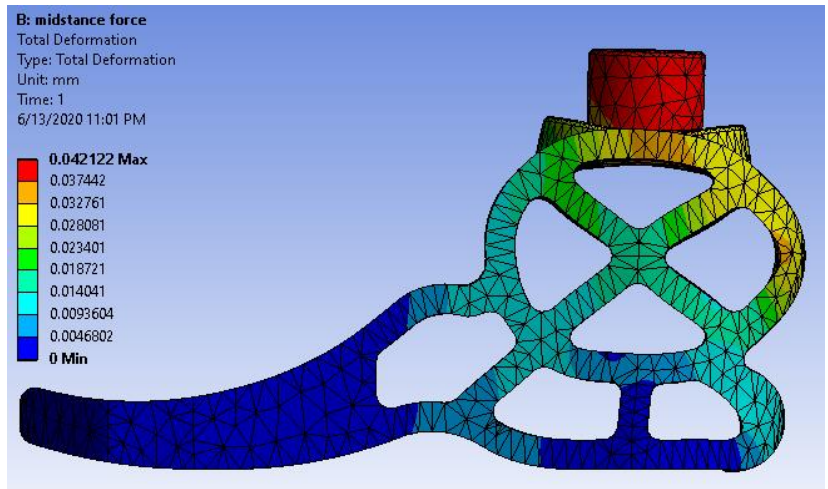

(b)

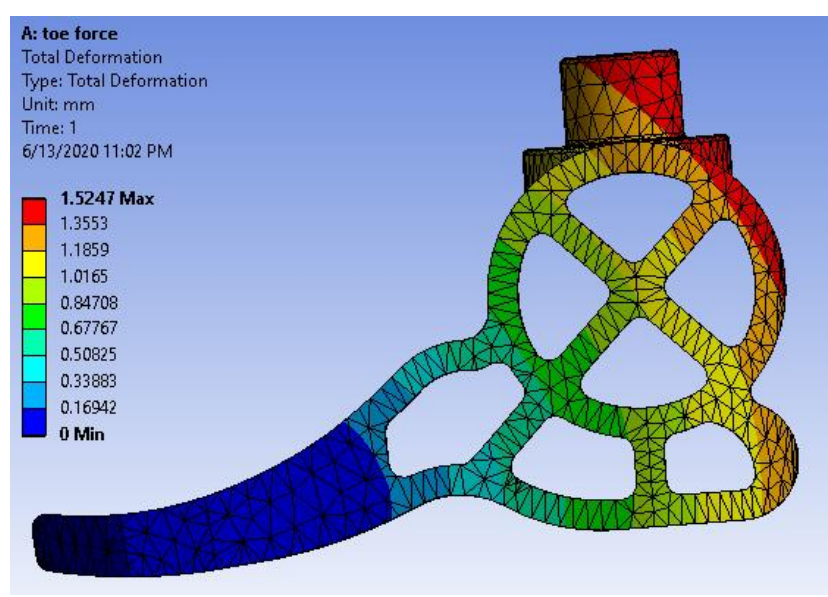

(c)

Gambar 6. Hasil total deformation pada model (a) posisi heel strike; (b) posisi midstance; (c) posisi toe-off 
Boundary condition pada model prostetik engkel kaki dibatasi dengan tumpuan (fix support) ditempatkan pada 3 posisi tahapan siklus berjalan yaitu pada posisi heel strike, posisi midstance, dan posisi toe-off. Dengan sudut kemiringan posisi heel strike diasumsikan sebesar 15 derajat dari bidang datar sebagai kontak awal dengan ground. Pada posisi midstance diberikan sudut beban sebesar 5 derajat karena posisi tubuh tegak mengalami kemiringan yang condong kedepan sehingga ada tahanan lebih dari tubuh bagian depan yang mengakibatkan adanya sudut tersebut. Posisi toe-off disetting dengan sudut sebesar 10 derajat sebagai tahap akhir fase stance menuju fase swing untuk tahapan langkah selanjutnya.

Load yang diberikan sebesar 250 sampai 500 N. Nilai tersebut diasumsikan untuk mencakup setengah berat tubuh manusia antara 50 sampai $100 \mathrm{~kg}$ dikalikan dengan gaya gravitasi. Momen putar searah dengan jarum jam pada pusat soket betis dengan radius $10 \mathrm{~mm}$ berkisar 2500 sampai 5000 Nmm ketika prostetik engkel kaki diberi gaya putar. Gambar 5 menunjukkan ilustrasi simulasi yang dilakukan pada kondisi batas (boundary condition) tiga posisi tahapan siklus berjalan manusia.

\section{Hasil dan Pembahasan}

\subsection{Deformation}

Untuk mengetahui perubahan bentuk model yang terjadi ketika diberi load maka digunakan total deformation sebagai parameter analisis. Hasil dari total deformasi dapat dipresentasikan bahwa pada posisi toe-off mengalami perpindahan (displacement) yang lebih besar dari pada posisi midstance dan heel strike. Displacement terbesar dari posisi toe-off adalah 1,52 mm yaitu ketika diberi force sebesar 500 $\mathrm{N}$. Sedangkan posisi heel strike dan midstance relatif lebih kecil dan hampir sama yaitu sebesar 0,067 mm dan 0,042 mm dengan beban yang sama. Kurva defleksi dari pemberian load $250 \mathrm{~N}$ sampai $500 \mathrm{~N}$ dengan tiga posisi prostetik engkel kaki dapat dilihat pada Gambar 6. Sedangkan bentuk deformasi yang terjadi pada tiga posisi tersebut dengan maksimum load dapat diilustrasikan pada Gambar 7.

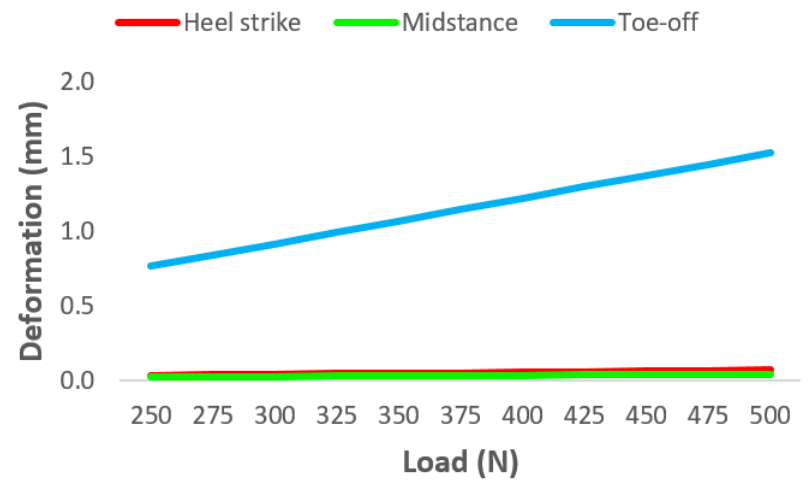

Gambar 7. Perbandingan deformation pada tiga posisi ketika diberi load

Stiffness dipelajari guna mengetahui nilai kekakuan material pada bentuk model sebagaimana rumus pada Persamaan 1 [17].

$$
K=\frac{F}{d}
$$

Dimana $K$ merupakan stiffness $(\mathrm{N} / \mathrm{mm}), F$ adalah force $(\mathrm{N})$, dan $d$ adalah deformation $(\mathrm{mm})$. Sedangkan untuk mencari stiffness dari moment menggunakan rumus Persamaan 2 [18]. Dimana $M$ merupakan moment (Nmm) dan $\theta$ adalah sudut rotasi (rad).

$$
K=\frac{F}{\theta}
$$

Dari persamaan diatas maka dapat ditemukan stiffness yang didapat pada posisi heel strike, midstance, dan toe-off adalah sebesar $7433 \mathrm{~N} / \mathrm{mm}, 11870 \mathrm{~N} / \mathrm{mm}$, dan $328 \mathrm{~N} / \mathrm{mm}$ secara berturut-turut. Posisi toe-off dengan bentuk model tersebut mempunyai stiffness yang paling kecil karena memiliki displacement yang paling besar juga. Disisi lain, hasil deformation terbesar ketika diberi maximum moment terjadi pada posisi toe-off yaitu sebesar $0,036 \mathrm{~mm}$. Hasil deformation dari setiap pemberian moment ditampilkan pada Gambar 8.

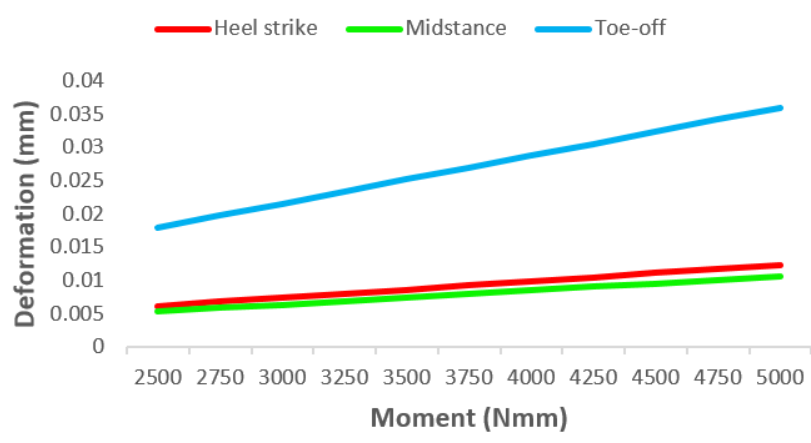

Gambar 8. Perbandingan deformation pada tiga posisi ketika diberi moment

\subsection{Stress}

Von mises stress digunakan sebagai parameter analisis berikutnya, ditujukan untuk mengetahui hasil maximum stress yang terjadi pada prostetik engkel kaki dengan pemberian load dan moment yang sama dalam stepnya. Hasil analisis menunjukan bahwa dari ketiga posisi tersebut dengan pemberian beban yang sama dengan sudut yang berbeda, posisi midstance memiliki stress paling rendah yaitu sebesar 2,29 $\mathrm{MPa}$ seperti yang ditampilkan pada Gambar 9.

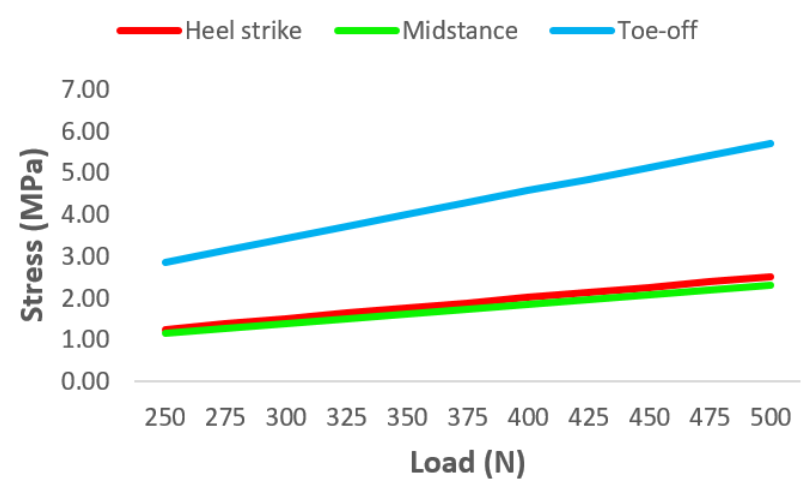

Gambar 9. Korelasi stress dan load pada tiga posisi model 
Hal tersebut dikarenakan posisi midstance bertumpu dengan dua fix support di area telapak kaki depan dan belakang, sehingga distribusi stress lebih merata. Sedangkan stress yang paling besar yaitu 5,71 MPa terjadi pada tumpuan telapak kaki bagian depan saat posisi toe-off seperti ditunjukan pada Gambar 9. Dengan safety factor 4,7 maka desain model prostetik engkel kaki tersebut terkategori aman karena stress tersebut masih dibawah batas yield stre[6ngth dari material ABS [19][20].

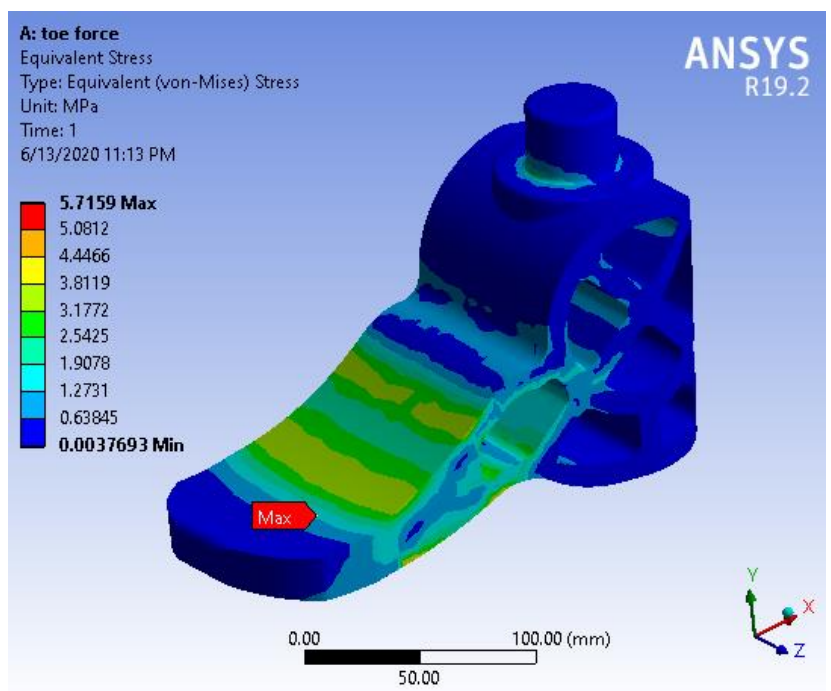

Gambar 10. Hasil maximum stress pada model dengan posisi toeoff

Disisi lain dari ketiga posisi prostetik engkel kaki ini ketika diberi momen yang sama menujukkan hasil stress yang sangat mirip. Hasil maximum equivalent stress dengan pemberian maximum moment dari yang terbesar yaitu 0,067 MPa dengan posisi toe-off, diikuti 0,602 MPa dengan posisi midstance, dan selanjutnya $0,061 \mathrm{MPa}$ dari posisi heel strike seperti yang ditunjukan pada Gambar 11.

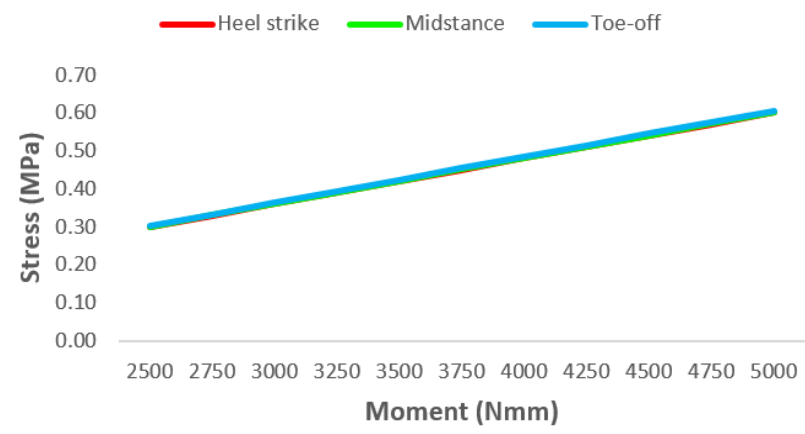

Gambar 11. Korelasi stress dan moment pada tiga posisi model

\subsection{Strain Energy}

Parameter analisis yang terakhir adalah strain energy difungsikan untuk mengukur energi regangan yang tersimpan. Dari jumlah load yang diberikan, hasilnya menunjukkan bahwa pada posisi toe-off menyimpan energi paling besar yaitu sebesar $0,6 \mathrm{~mJ}$ dengan area maximumnya terletak pada telapak kaki persis dengan titik maximum stressnya. Grafik defleksi analisis dari hasil simulasi strain energi dengan pembanding load digambarkan pada Gambar
12. Selain itu, hasil dari perbandingan tiga posisi siklus berjalan ketika diaplikasikan moment dapat dilihat pada Gambar 13. Kurva grafik tersebut terlihat seperti satu garis saja dikarenakan nilainya yang mendekati sama. Jumlah energi yang terbesar dengan maximum moment berkisar pada $0,0015 \mathrm{~mJ}$ dari ketiga posisi boundary condition tersebut.

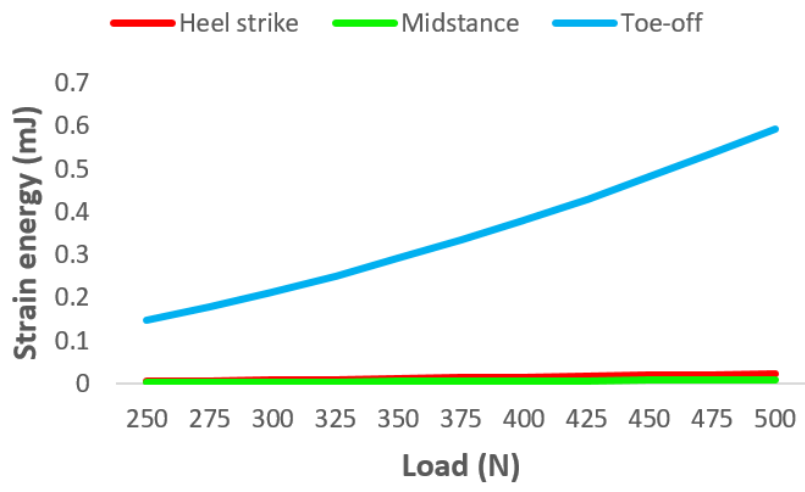

Gambar 12. Nilai strain energy ketika diberi load pada tiga posisi model

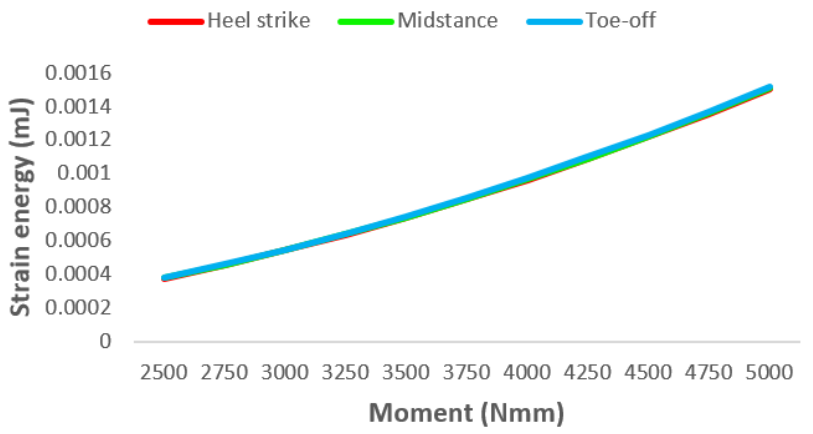

Gambar 13. Nilai strain energy ketika diberi moment pada tiga posisi model

\section{Kesimpulan}

Model prostetik engkel kaki ini dirancang dan dianalisis untuk mengetahui kekuatan dan kelayakan sebelum model ini di fabrikasi. Berdasarkan hasil analisis dari tiga boundary condition siklus berjalan yaitu pada posisi heel strike, midstance, dan toe-off diatas menunjukan bahwa model ini mampu menahan load sampai $500 \mathrm{~N}$ dan momen sampai $5000 \mathrm{Nmm}$.

Hasil deformasi terbesar terjadi pada posisi toe-off yaitu sebesar 1,52 mm ketika diberi maximum load dan 0,036 mm ketika diberi maximum moment. Namun stiffness posisi toe-off lebih rendah dari pada posisi yang lain yaitu sebesar $328 \mathrm{~N} / \mathrm{mm}$. Maximum stress juga terjadi pada posisi toe-off sebesar 5,71 Mpa. Dengan safety factor 4,7 maka desain model prostetik engkel kaki tersebut terkategori aman karena stress tersebut masih dibawah batas yield strength dari material ABS. Strain energy tebesar terletak diarea telapak kaki bagian depan pada posisi toe-off sebesar 0,6 mJ.

Dari pembahasan diatas dapat disimpulkan bahwa rancangan desain ini mempunyai keunggulan yang fleksibel karena betuk lengkung yang elastis mengadopsi konsep compliant mechanism dan pemanfaatan strain energy. Untuk penelitian kedepan akan dicoba fabrikasi sebuah prototype 
$3 D$ printer dan dilakukan experiment dari prototype prostetik engkel kaki tersebut.

\section{Daftar Pustaka}

[1] J. Herman, "Resiliensi pada Penyandang Tuna Daksa (Doctoral dissertation, Universitas Gadjah Mada)," 2015.

[2] G. T. Klein, Y. Lu, and M. Y. Wang, "3D printing and neurosurgery--ready for prime time?," World Neurosurg., vol. 80, no. 3-4, pp. 233-235, 2013.

[3] C. L. Ventola, "Medical applications for 3D printing: current and projected uses," Pharm. Ther., vol. 39, no. 10, p. 704, 2014.

[4] R. Versluys, P. Beyl, M. Van Damme, A. Desomer, R. Van Ham, and D. Lefeber, "Prosthetic feet: State-of-the-art review and the importance of mimicking human ankle-foot biomechanics," Disabil. Rehabil. Assist. Technol., vol. 4, no. 2, pp. 65-75, 2009.

[5] W. L. Childers and K. Z. Takahashi, "Increasing prosthetic foot energy return affects whole-body mechanics during walking on level ground and slopes," Sci. Rep., vol. 8, no. 1, pp. 1-12, 2018.

[6] T. T. Nguyen, H. G. Le, T.-P. Dao, and S.-C. Huang, "Evaluation of structural behaviour of a novel compliant prosthetic ankle-foot," in 2017 International Conference on Mechanical, System and Control Engineering (ICMSC), 2017, pp. 58-62.

[7] S. Ertis, J. Kearns, and S. Maniskas, "Design and testing of a low cost prosthetic foot," 2012.

[8] K. Fite, J. Mitchell, F. Sup, and M. Goldfarb, "Design and control of an electrically powered knee prosthesis," in 2007 IEEE 10th International conference on rehabilitation robotics, 2007, pp. 902-905.

[9] P. Cherelle et al., "The Ankle Mimicking Prosthetic Foot 3 Locking mechanisms, actuator design, control and experiments with an amputee," Rob. Auton. Syst., vol. 91, pp. 327-336, 2017.
[10] M. Liu, P. Datseris, and H. H. Huang, "A prototype for smart prosthetic legs-analysis and mechanical design," in Advanced Materials Research, 2012, vol. 403, pp. 1999-2006.

[11] A. D. Junianto and D. Kuswanto, "Desain Kaki Palsu untuk Membantu Aktivitas Berjalan pada Tuna Daksa Transtibial dengan Menggunakan Rapid Prototyping dan Reverse Engineering," J. Sains dan Seni ITS, vol. 7, no. 1, pp. 15-18, 2018.

[12] S. Moaveni, Finite element analysis theory and application with ANSYS, 3/e. Pearson Education India, 2011.

[13] D. L. Logan, A first course in the finite element method. Cengage Learning, 2011.

[14] G. Li, Z. Liu, G. Jiang, H. Liu, and H. Xiong, "Numerical simulation of the influence factors for rotary kiln in temperature field and stress field and the structure optimization," Adv. Mech. Eng., vol. 7, no. 6, p. 1687814015589667, 2015.

[15] R. Zou et al., "Isotropic and anisotropic elasticity and yielding of 3D printed material," Compos. Part B Eng., vol. 99, pp. 506-513, 2016.

[16] V. V Volkov-Muzylev, L. E. Vendland, Y. A. Borisov, and A. N. Demidov, "Possibility of ABS polymers application for centrifugal wheel model manufacture by additive printing," in AIP Conference Proceedings, 2019, vol. 2141, no. 1, p. 40001.

[17] F. Baumgart, "Stiffness-an unknown world of mechanical science?," Inj. J. Care Inj., vol. 31, no. 2, pp. 14-23, 2000.

[18] J. M. Tinjum and R. W. Christensen, "Site investigation, characterization and assessment for wind turbine design and construction," in Wind Energy Systems, Elsevier, 2011, pp. 28-45.

[19] R. K. Bansal, A textbook of strength of materials. Laxmi Publications, 2010.

[20] A. Padhi et al., "Increase Factor of Safety of Go-Kart Chassis during Front Impact Analysis," Int. J. Innov. Res. Sci. Technol., vol. 3, no. 04, 2016. 